\title{
Analyses on Thermal Insulation Performance of Earth-Covered Wall for Residential Underground Space by Using a Numerical Simulation Program
}

\author{
Byungseon Sean Kim ${ }^{1}$ and Kwangho Kim*2 \\ ${ }^{1}$ Professor, Department of Architectural Engineering, Yonsei University, Korea \\ ${ }^{2}$ Doctoral Candidate, Department of Architectural Engineering, Yonsei University, Korea
}

\begin{abstract}
The purpose of this study is to provide the regional insulation criterion of earth-covered walls for underground residential buildings in Korea by using a numerical simulation program. This study was started from the idea that thermal condition of underground residential space must be closer to that of aboveground residential space. According to the result of this study, the underground temperature declines as the depth from the ground level goes deeper and closer to about $9 \mathrm{~m}$, and then maintain some steady value from about $9 \mathrm{~m}$ of the depth. The minimum thermal insulation by depths was deduced by finding the U-factors that make the inside-surface temperature of the earth-covered wall closer to that of the aboveground wall.
\end{abstract}

Keywords: underground space; thermal insulation; heat flux; simulation

\section{Introduction}

Underground spaces are more and more common in large cities, due to limitations in space availability. This is the case of car parks, commercial centers, subway stations, pedestrian corridors or automobile underground lanes and etc [Bouchet, 1996].

Like these cities, Seoul, the largest city in Korea, has recently reached the limit of space availability due to its population explosion. Its usage of underground space may be expanded from temporary space to residential space in the future.

Although most of the existed ground-coupled methods can predict the heat flux variations along the groundcoupled surfaces assuming that the insulation distribution is known, no existed method comes up with any guidelines on the adequate insulation that provides a desirable heat flux profile along the underground building envelope for residential spaces.

To decrease the heat transfer between underground and below-grade surfaces, thermal insulation is generally placed along below-grade surfaces. The question is how much amount of insulation is required to make the thermal environment of underground residential space at the level of ground space.

For the most above-grade surfaces such as walls and roofs on the ground level, their solutions consist of placing the insulation uniformly along the entire surfaces. However, in case of below-grade surfaces, the appropriate distribution of insulation is difficult to

*Contact Author: Kwangho Kim, Doctoral Candidate, Architectural Engineering, Yonsei University, Seoul 120-749

Tel: +(82-2) 2123-2791 Fax: +(82-2) 365-4668

e-mail: infrazign@yonsei.ac.kr

(Received November 12, 2003; accepted September 13, 2004) determine since the temperature of underground is different by depths.

A large number of studies have been made on the insulation distribution of underground space. Claesson and Eftring [Claesson \& Eftring, 1980] carried that the optimum insulation distribution around a conductive structure is obtained by using basic thermodynamic principles when heat flux along each boundary surface is constant.

In this paper, their optimization criterion provides the insulation distribution along the inner surfaces of the envelope of an earth-covered structure that minimizes the annual total heat loss or gain from each groundcoupled surface. However, it is valid only under steadystate conditions and therefore, only long-term solution is considered.

In comparison with the study of Claesson and Eftring that focuses on determining where to place a given amount of thermal insulation, Choi and Krarti [Choi \& Krarti, 2000] conducted researches on how much thermal insulation is needed to minimize the total heat loss from the underground structure.

They determined the optimal insulation distribution for basement floor and walls. In particular, they derived that the insulation should be increased with the depth and the lower corners of the basement require the largest amount of insulation. But their study is thought not to consider a climate of region.

In case of a temperate region, in summer, its underground temperature declines as the depth from the ground level increases because of hot weather. On the contrary, in winter, its ground temperature rises as the depth from the ground level increases because of cold weather. Both temperatures maintain a certain steady value from a certain depth from the ground level. 
Therefore, in winter, the insulation of the basement may be increased as the depth is closer to the ground level due to the effect of cold weather with some degrees below zero.

As other studies, Speltz [Speltz, 1980], Shipp et al. [Shipp et al., 1981], Szydlowski and Kuehn [Szydlowski \& Kuehn, 1981], and Krarti and Claridge [Krarti \& Claridge, 1990] developed the existed methods that determined whether or how much thermal insulation is warranted based on economical evaluation.

The purpose of this study is to provide the regional insulation criterion of earth-covered walls for underground residential buildings in Korea by using a numerical simulation program.

This study was started from the idea that thermal condition of underground residential space must be closer to that of aboveground residential space. The procedure of the study is described as follows:

- The program to predict the underground temperature with the depth for 8,760 hours (=1 year) was developed by using several equations from precedent studies.

- 32 wall-cases were made by phasing U- factor based on the Koran standard that suggests basic constitutions of wall-layer components and minimum U-factors of building components for energy savings.

- Two kinds of temperatures were used for simulation. One is the underground temperature that is calculated by the prediction program. Another is the outdoor temperature from the Seoul weather data, made by the society of air-conditioning \& refrigerating engineers of Korea.

- The inside-surface temperature of each wall- case, coping with the underground temperature, was obtained by the numerical simulation program. And also the inside-surface temperature of the aboveground wall with the minimum $\mathrm{U}$-factor from the Korean insulation standard, coping with the outdoor temperature, was acquired by the numerical simulation program. The wallcase was selected by the rule that the former temperature should be closer to the latter temperature.

\section{Thermal characteristics of underground}

The thermal environment of the underground is different from that of the aboveground because soil has two functions of thermal storage and insulation in comparison with air.

Figure 1 shows the variation of monthly average underground temperature of Seoul for 30 years. The ground surface is thermally influenced by air temperature and solar radiation, and this influence affects the underground by a certain depth. Although heat of the ground surface, made by air and solar, is transferred below the ground, the transfer of its heat to soil by soil is retarded by the thermal storage property of soil. This phenomenon is called time-lag effect.

Therefore, the underground temperature of summer with the depth goes lower because of the thermal storage property of soil. Its temperature of winter has a movement against that of summer. Two temperatures converges into a specific point below a certain depth. Thermal characteristics of the underground in Korea are described as follows;

In figure 1 , Korea has 4 seasons. Average underground-water temperature is about $15^{\circ} \mathrm{C}$ and annual underground temperature is varied from -5 to $25^{\circ} \mathrm{C}$ by heat of the ground from air and solar.

However, the underground below $5 \mathrm{~m}$ of the depth from the surface, is not affected by heat of the ground surface. And also the underground temperature below $9 \mathrm{~m}$ of the depth converges into the specific point $14.2^{\circ} \mathrm{C}$ in case of Seoul in Korea.

- In figure 2, comparing outdoor temperature of the Seoul weather data with the underground temperatures that were measured at $1 \mathrm{~m}, 3 \mathrm{~m}$, and $5 \mathrm{~m}$ of the depth from the ground level, there is a time-lag effect comes out at $5 \mathrm{~m}$ of the depth.

Although the underground temperature at $1 \mathrm{~m}$ of the depth is varied in accordance with the outdoor temperature, its temperature at $5 \mathrm{~m}$ of the depth has a movement against the outdoor temperature in that Mayís underground temperature is the lowest in comparison with the outdoor temperature. According to the analysis result of the measured data at $1 \mathrm{~m}, 3 \mathrm{~m}$, and $5 \mathrm{~m}$ of the depth, the interval of time-lag effect is one week per $30 \mathrm{~cm}$.

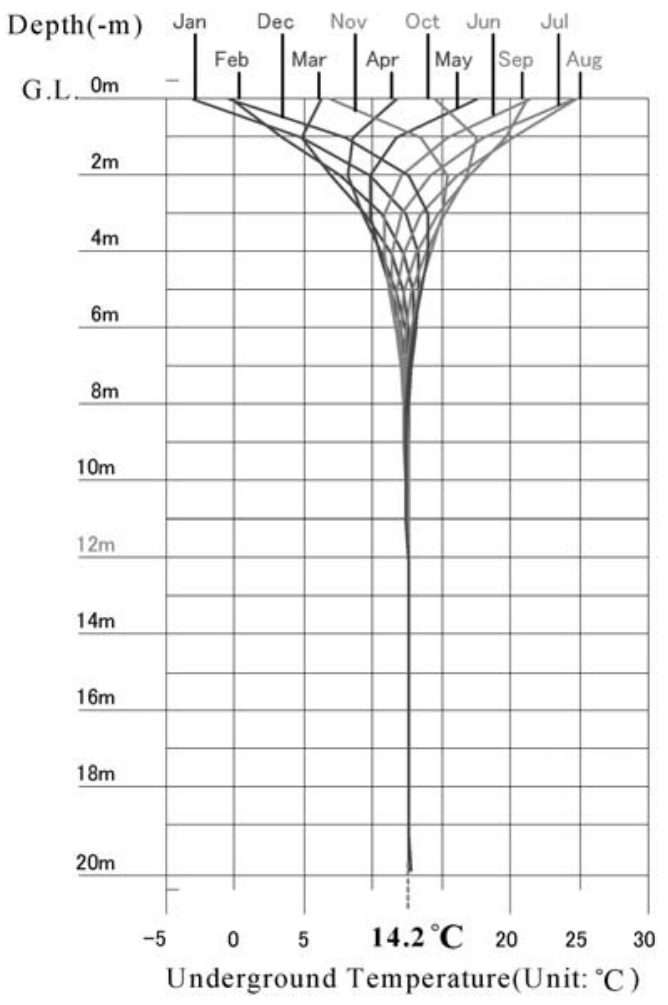

Fig.1. The Variation of The Underground Temperature 


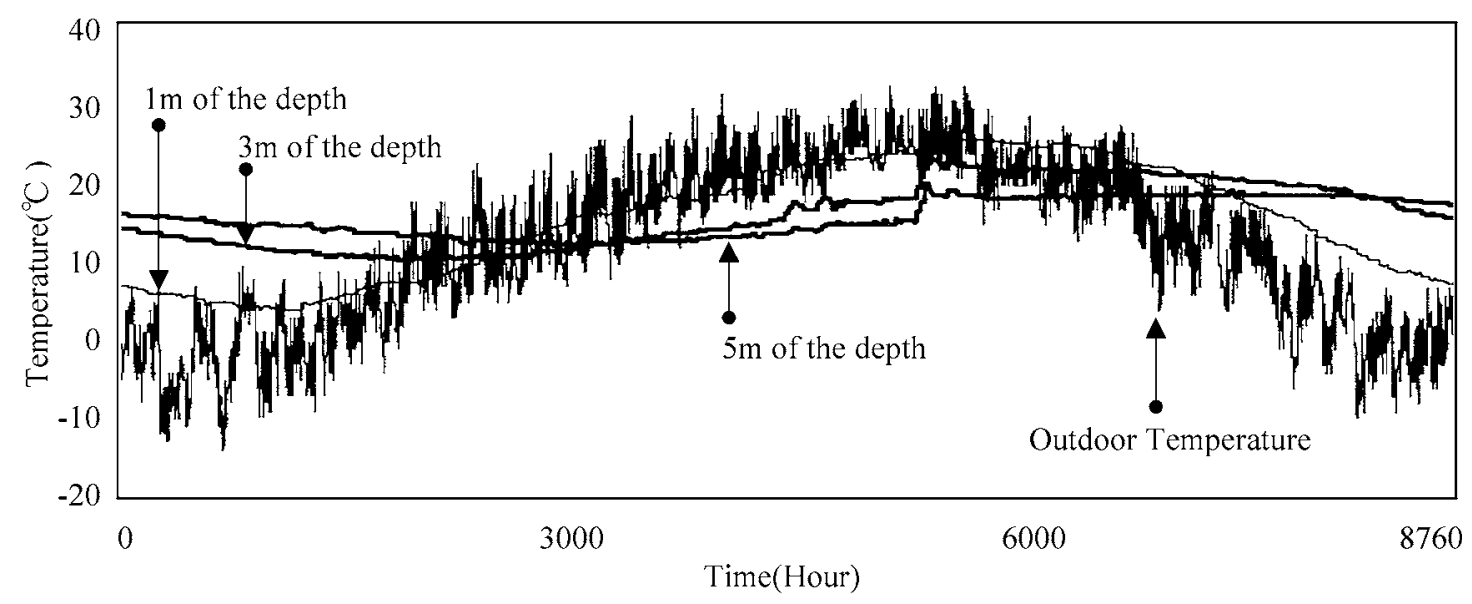

Fig.2. Variations of The Underground Temperature And Outdoor Temperature

Table 1. Regional Minimum Insulation Standards of Residential Building Components In Korea, 2001.4.

\begin{tabular}{llll}
\hline \multicolumn{1}{c}{ Building Components } & Central Region & South Region & Jeju Island \\
\hline Exterior \& Underground Walls & Less Than 0.50 & Less Than 0.65 & Less Than 1.00 \\
Roof Or Ceiling of Top Floor & Less Than 0.35 & Less Than 0.45 & Less Than 0.65 \\
Side Walls of Apartments & Less Than 0.40 & Less Than 0.60 & Less Than 0.70 \\
Windows & Less Than 2.90 & Less Than 3.10 & Less Than 5.00 \\
\hline
\end{tabular}

* This Table 1 focuses on U-factors

\section{Thermal insulation standard of Korea}

For energy savings, minimum U-factors and basic constitutions of residential building components are prescribed in the rules of Korea architectural laws and regulations.

Although the thermal insulation standard by regions and components, one of several standards, is arranged for residential buildings as in table 1 [Song, 1998], it focuses on the aboveground spaces of buildings. There is no thermal insulation standard, considering the thermal characteristics of the underground, for underground residential spaces of buildings.

From the above mention at section 2, it is deduced that if the insulation standard of table 1 is applied to the underground, it may be allowable to be reduced in winter and available in summer. The reason is that the underground temperature with the depth is lower because of the thermal storage property of soil in summer but its temperature in winter has a movement against that in summer.

\section{Development of the program to predict hourly underground temperature by regions and depths}

There is few data on the underground temperature from the meteorological observatory in Korea which does not measure the underground temperature below $5 \mathrm{~m}$ of the depth.

In this study, the method to predict the underground temperature is based on the periodic function of sine or cosine with considering the period of air temperature under the assumption that the underground is semiinfinite solid. It furnished the numerical simulation program with hourly-and-regional data about the underground temperature.

\subsection{Algorithm of the prediction program}

Energy equation on $\mathrm{T}$, the underground temperature, was reduced to:

$$
\frac{\partial^{2} T}{\partial \chi}=\frac{1}{\alpha} \frac{\partial T}{t}
$$

where $\chi$ is the depth from the ground, t is time, and $\alpha$ is the thermal diffusivity of soil.

Equation (1) was transformed into the following equation (2) by Mayer's complex function [Mayer, 1971]:

$$
T=T_{a r}+T_{a m} \cdot \operatorname{EXP}\left(-\chi \sqrt{\frac{w}{2 \alpha}}\right) \cdot \cos \left(w t-\sqrt{\frac{w}{2 \alpha}}+C\right)
$$

where $\mathrm{T}_{\mathrm{av}}$ is the average underground temperature at the steady layer (converges into the specific point $14.2^{\circ} \mathrm{C}$ below $9 \mathrm{~m}$ of the depth in case of Seoul in Korea), $\mathrm{T}_{\mathrm{am}}$ is a half of the difference between the lowest and the highest of monthly ground-surface temperatures, $w$ is the angular velocity, and $\mathrm{C}$ is the topological revised coefficient. To calculate the underground temperature of Seoul, the variables of the equation (1) are set up as the followings [S. Jeong, 1986]:

- $w$, the angular velocity, becomes $2 \pi / 365$ in that it regards one year as a period to estimate the daily underground temperature of Seoul.

- $\mathrm{T}_{\mathrm{am}}$ is assumed as $15^{\circ} \mathrm{C}$

- $\mathrm{T}_{\mathrm{av}}^{\mathrm{am}}$ is assumed as $14.2^{\circ} \mathrm{C}$ (see figure 1)

- C, the topological revised coefficient, is set up 2.424 by using the maximum value of the underground temperature that is measured by the meteorological observatory.

$\alpha$, the thermal diffusivity of soil, is set up 0.0769 $\mathrm{m}^{2} /$ day, the average value from $0 \mathrm{~m}$ to $5 \mathrm{~m}$. 


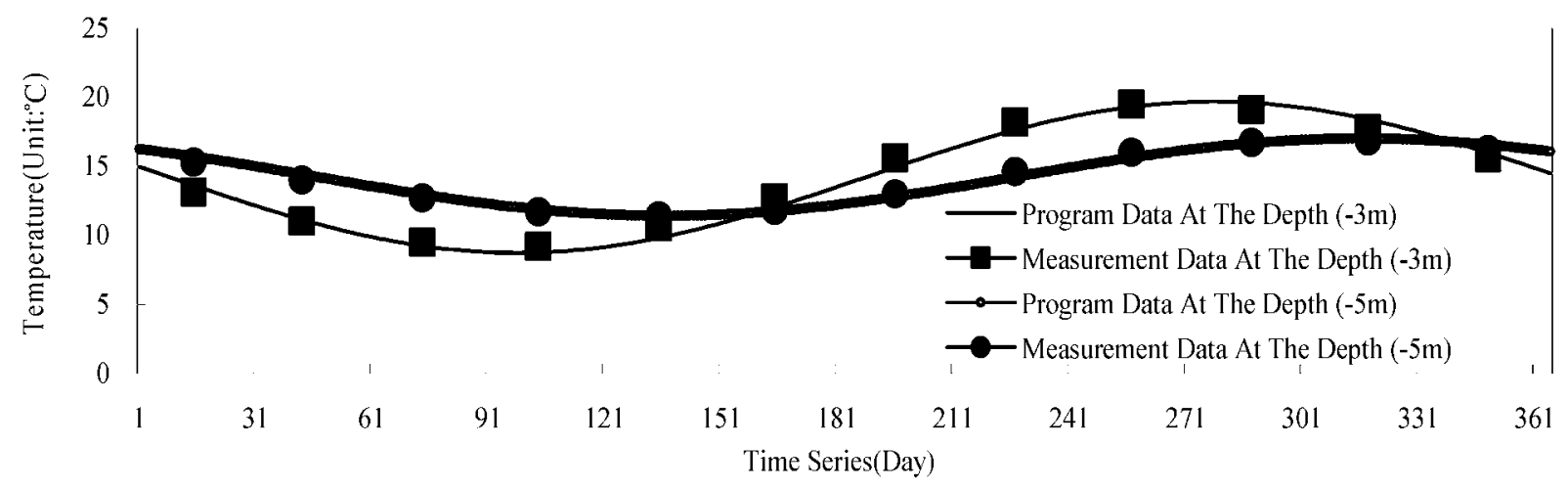

Fig.3. Comparison Of Program Data With Measurement Datan

\subsection{Verification test of the program}

In comparison of the calculated data by the prediction program with the measurement data from meteorological observatory, the difference between two data is less than $3 \%$ as seen in figure 3 . It is thought that the prediction program gains public confidence.

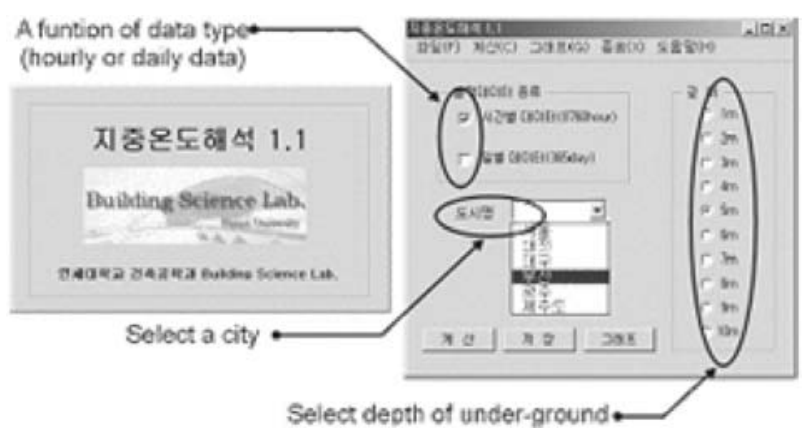

Fig.4. User Interface Of The Prediction Program

\section{Thermal insulation standard of the earth-covered wall for residential buildings \\ 5.1 Heat flux under a steady state}

\subsubsection{Simulation condition}

To analyze the heat flow and the inside-surface temperature of the earth-covered wall, the numerical simulation program, based on finite different method and response factor method like CFD program, was used in this study. The numerical simulation was performed by the following assumptions:

- The inner insulation and the outer insulation were applied in that the wall structure with these two insulations and the middle insulation can be excessively thick. Therefore, the middle insulation was omitted.

- The temperature of the earth-covered walls which compose the underground space was only affected by the underground temperature.

- The minimum thermal insulation standards did not consider condensation and was calculated by using only the heat flow of the wall structure, coping with the underground temperature.

- Residential basement space was under air- conditioning. Its humidity was established as the fixed value, $60 \%$.

\subsubsection{Simulation model and input data}

The basement model had two floors and was divided into three typical parts as in figure 5(a).

Part A is the ceiling part of the basement model between $0.7 \mathrm{~m}$ and $3 \mathrm{~m}$ of the depth from the surface of the ground. B is the floor part of the basement model between $3 \mathrm{~m}$ and $6 \mathrm{~m}$ of the depth. $\mathrm{C}$ is the bottom part of the basement model between $6 \mathrm{~m}$ and $9 \mathrm{~m}$ of the depth. Input data as a boundary condition were assumed as in table 2 .

Table 2. Input Data for the Steady-state Simulation

\begin{tabular}{l|l|l}
\hline \multicolumn{2}{l|}{ Items } & Boundary Condition \\
\hline \multirow{4}{*}{ Dry Bulb } & Inside & Set-point : $20^{\circ} \mathrm{C}$ \\
\cline { 2 - 3 } & Weather & $\begin{array}{l}\text { Underground Temperature } \\
\text { At The Depth Of } 1 \mathrm{~m}, 2 \mathrm{~m}, \cdots \\
10 \mathrm{~m}\end{array}$ \\
\hline $\begin{array}{l}\text { Thermal } \\
\text { Conductivity }\end{array}$ & Inside & $7.20 \mathrm{kcal} / \mathrm{m}^{2} \mathrm{~h}^{\circ} \mathrm{C}(8.37 \mathrm{~W} / \mathrm{mK})$ \\
\cline { 2 - 3 } & Outside & $25.0 \mathrm{kcal} / \mathrm{m}^{\circ} \mathrm{h}^{\circ} \mathrm{C}(29.0 \mathrm{~W} / \mathrm{mK})$ \\
\hline \multicolumn{2}{l}{ Running Time } & $8760 \mathrm{hr} / 365$ day \\
\hline
\end{tabular}

5.1.3 Heat flow of the basement model under a steady state

Figure 5 shows heat flow of the basement model, represented by the color.

In case of $\operatorname{Part}(\mathrm{A})(0.7 \sim 3 \mathrm{~m})$, the inside-surface temperature of the ceiling was the lowest in January because its heat flow was represented by blue color that means low temperature. However, its heat flow of July had a movement against that of January. The main reason is that the surface of the ground is affected by air temperature and solar radiation.

In case of Part(B)(3 6m), like Part(A), the insidesurface temperature of the earth-covered wall rose as it went deeper during the winter.

It still had been affected by the surface temperature of the ground.

In case of Part(C)(6 9m), the inside-surface 


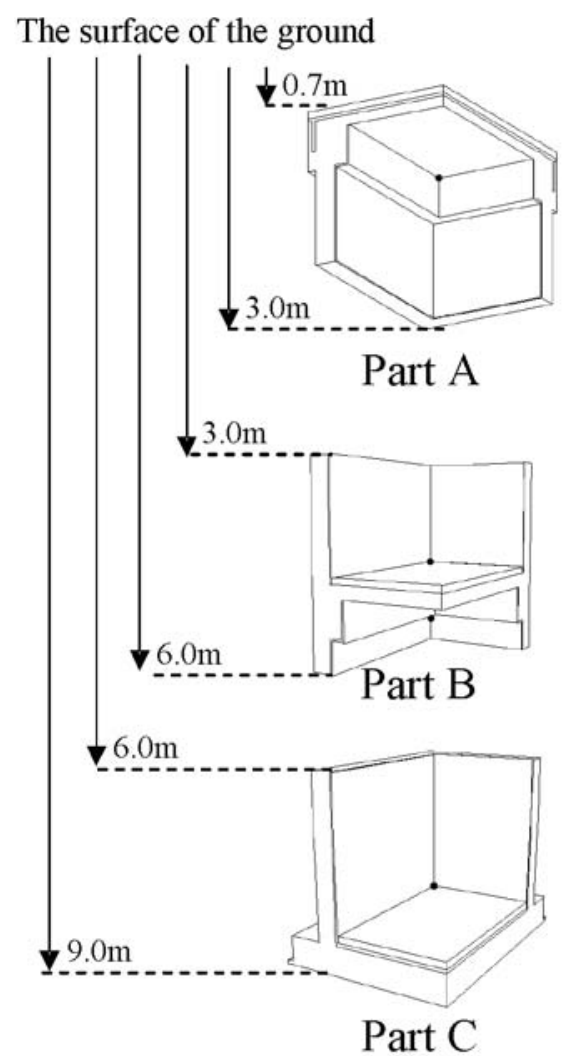

(a) Three Parts of Basement Model
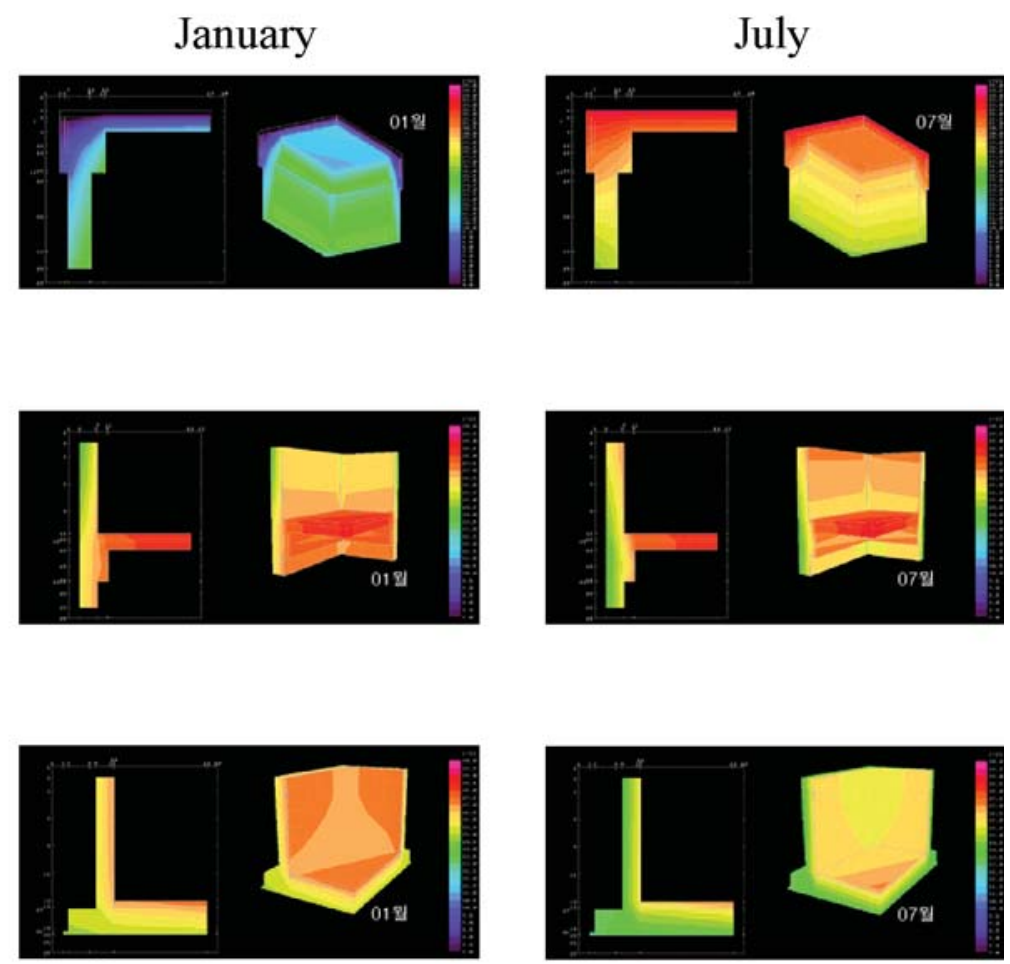

(b) Heat Flow of each Part in January and July

Fig.5. Heat Flow OF Basement Model

temperature of the earth-covered wall was not varied so much in summer or winter in that the underground temperature at the same depth reaches the steady value. After all, heat flow of the earth-covered wall is changed with regard to the underground temperature.

\subsection{Heat flux under a transient state}

\subsubsection{Simulation condition}

Section 5.1 shows how much heat flow of the earthcovered wall by depths from the surface of the ground is influenced by the underground temperature.

In this section, to find the minimum insulation of the earth-covered wall by regions and depths, it is need to conduct the numerical simulation under a transient state. This numerical simulation provides hourly data on the inside-surface temperature of the earth- covered wall coping with the underground temperature for 8,670 hours. It was performed by the following assumptions:

- To find the minimum insulation of the earthcovered wall, it was assumed that the built environment of underground residential spaces must be closer to that of aboveground residential spaces. Therefore, the wallcase was selected by the rule that the inside-surface temperature of the earth-covered wall by depths becomes closer to the inside-surface temperature of the aboveground wall with the minimum insulation standard of residential buildings.

- Basic conditions are equal to those of section 5.1. Outdoor temperature is extracted from the Seoul weather data, made by the society of air-conditioning \& refrigerating Engineers of Korea.

\subsubsection{The earth-covered wall model}

The basic constitution of the earth-covered wall model has 4 layers (mortar, concrete, insulation, and gypsum board) as in figure 4.32 cases were made by the physical values of 4 layers that were shown in Table 3 . They had U-factors between $0.25 \mathrm{kcal} / \mathrm{m}^{2} \mathrm{~h}^{\circ} \mathrm{C}$ and $4.12 \mathrm{kcal} / \mathrm{m}^{2} \mathrm{~h}^{\circ} \mathrm{C}$.

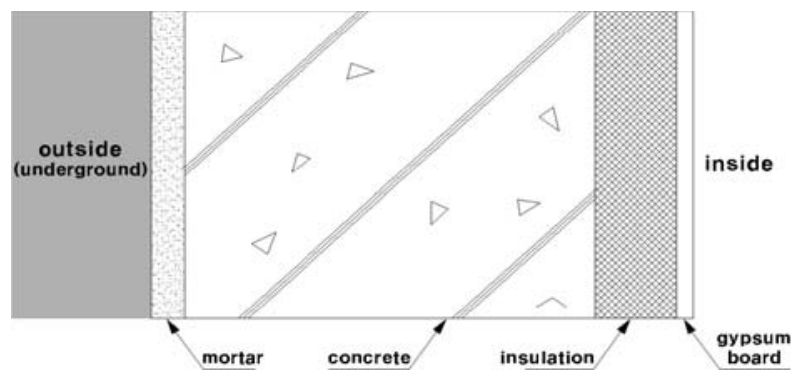

Fig.6. Four Layers of The Earth-Covered Wall Model 
Table 3. 32 Cases Of The Earth-Covered Wall

\begin{tabular}{|c|c|c|c|c|c|c|c|}
\hline \multirow[t]{3}{*}{ Case } & \multicolumn{6}{|c|}{4 Layers Of The Earth-Covered Wall Model } & \multirow[t]{3}{*}{ Table 1} \\
\hline & \multirow{2}{*}{$\begin{array}{c}\text { Mortar } \\
1.2 \mathrm{kcal} / \mathrm{mh}^{\circ} \mathrm{C} \\
\text { Thickness }(\mathrm{m})\end{array}$} & \multirow{2}{*}{$\begin{array}{c}\text { Concrete } \\
1.4 \mathrm{kcal} / \mathrm{mh}^{\circ} \mathrm{C} \\
\text { Thickness }(\mathrm{m})\end{array}$} & \multicolumn{2}{|c|}{ Insulation Layer } & \multirow{2}{*}{$\begin{array}{l}\text { Gypsum Board } \\
0.12 \mathrm{kcal} / \mathrm{mh}^{\circ} \mathrm{C} \\
\text { Thickness }(\mathrm{m})\end{array}$} & \multirow{2}{*}{$\begin{array}{l}\mathrm{U} \text {-factor } \\
\mathrm{kcal} / \mathrm{m}^{2} \mathrm{~h}^{\circ} \mathrm{C}\end{array}$} & \\
\hline & & & $\mathrm{kcal} / \mathrm{mh}^{\circ} \mathrm{C}$ & Thickness(m) & & & \\
\hline 1 & 0.02 & 0.30 & 0.04 & 0.025 & 0.01 & 1.06 & Jeju Region \\
\hline 2 & 0.02 & 0.30 & 0.04 & 0.050 & 0.01 & 0.63 & \\
\hline 3 & 0.02 & 0.30 & 0.04 & 0.075 & 0.01 & 0.45 & South Region \\
\hline 4 & 0.02 & 0.30 & 0.03 & 0.025 & 0.01 & 0.87 & \\
\hline 5 & 0.02 & 0.30 & 0.03 & 0.050 & 0.01 & 0.50 & Central Region \\
\hline 6 & 0.02 & 0.30 & 0.03 & 0.075 & 0.01 & 0.35 & Central Region \\
\hline 7 & 0.02 & 0.30 & 0.02 & 0.025 & 0.01 & 0.63 & \\
\hline 8 & 0.02 & 0.30 & 0.02 & 0.050 & 0.01 & 0.36 & \\
\hline 9 & 0.02 & 0.30 & 0.02 & 0.075 & 0.01 & 0.25 & \\
\hline 10 & 0.02 & 0.30 & - & - & 0.01 & 3.18 & \\
\hline 11 & 0.02 & 0.25 & 0.04 & 0.025 & 0.01 & 1.11 & \\
\hline 12 & 0.02 & 0.25 & 0.04 & 0.050 & 0.01 & 0.65 & South Region \\
\hline 13 & 0.02 & 0.25 & 0.04 & 0.075 & 0.01 & 0.46 & \\
\hline 14 & 0.02 & 0.25 & 0.03 & 0.025 & 0.01 & 0.90 & \\
\hline 15 & 0.02 & 0.25 & 0.03 & 0.050 & 0.01 & 0.51 & \\
\hline 16 & 0.02 & 0.25 & 0.03 & 0.075 & 0.01 & 0.36 & \\
\hline 17 & 0.02 & 0.25 & 0.02 & 0.025 & 0.01 & 0.65 & Jeju Region \\
\hline 18 & 0.02 & 0.25 & 0.02 & 0.050 & 0.01 & 0.36 & \\
\hline 19 & 0.02 & 0.25 & 0.02 & 0.075 & 0.01 & 0.25 & \\
\hline 20 & 0.02 & 0.25 & - & - & 0.01 & 3.59 & \\
\hline 21 & 0.02 & 0.20 & 0.04 & 0.025 & 0.01 & 1.15 & \\
\hline 22 & 0.02 & 0.20 & 0.04 & 0.050 & 0.01 & 0.67 & \\
\hline 23 & 0.02 & 0.20 & 0.04 & 0.075 & 0.01 & 0.47 & \\
\hline 24 & 0.02 & 0.20 & 0.03 & 0.025 & 0.01 & 0.93 & \\
\hline 25 & 0.02 & 0.20 & 0.03 & 0.050 & 0.01 & 0.52 & \\
\hline 26 & 0.02 & 0.20 & 0.03 & 0.075 & 0.01 & 0.36 & \\
\hline 27 & 0.02 & 0.20 & 0.02 & 0.025 & 0.01 & 0.67 & \\
\hline 28 & 0.02 & 0.20 & 0.02 & 0.050 & 0.01 & 0.36 & \\
\hline 29 & 0.02 & 0.20 & 0.02 & 0.075 & 0.01 & 0.25 & \\
\hline 30 & 0.02 & 0.20 & - & - & 0.01 & 4.12 & \\
\hline 31 & 0.02 & 0.40 & - & - & 0.01 & 2.59 & \\
\hline 32 & 0.02 & 0.50 & - & - & 0.01 & 2.18 & \\
\hline
\end{tabular}

5.2.3 The minimum thermal insulation of the earthcovered wall

Figure 5 shows the variation of the inside-surface temperature of the wall model with $0.5 \mathrm{kcal} / \mathrm{m}^{2} \mathrm{~h}^{\circ} \mathrm{C}$, the minimum insulation standard of the central region in table1, that copes with the outdoor temperature. Although the outdoor temperature fluctuated from about $-14^{\circ} \mathrm{C}$ to $31^{\circ} \mathrm{C}$, this inside-surface temperature steadily maintained about $20^{\circ} \mathrm{C}$, close to the set-point. It means that this insulation level is desirable in the central region such as Seoul.

Figure 6 and 7 show the variations of inside-surface temperatures of 8 cases, at $1 \mathrm{~m}$ of the depth from the surface of the ground, that cope with the underground temperature.

Cases with about $0.6 \mathrm{~s} \mathrm{kcal} / \mathrm{m}^{2} \mathrm{~h}^{\circ} \mathrm{C}$ have similar variations to the variation of the inside-surface temperature that copes with the outdoor temperature (see case(7) with $0.63 \mathrm{kcal} / \mathrm{m}^{2} \mathrm{~h}^{\circ} \mathrm{C}$ ). Cases with less than $0.5 \mathrm{kcal} / \mathrm{m}^{2} \mathrm{~h}^{\circ} \mathrm{C}$ has high insulation level than that of the aboveground wall (see case(3)(5)).

In winter, Cases with about more than $0.7 \mathrm{kcal} / \mathrm{m}^{2} \mathrm{~h}^{\circ} \mathrm{C}$ have lower variations than the variation of the insidesurface temperature that copes with the outdoor temperature. It means that their insulation levels are inadequate to the underground at the central region (see case(1)(4)(10)). In particular, the inside-surface temperature of case $(10)$ with $3.18 \mathrm{kcal} / \mathrm{m}^{2} \mathrm{~h}^{\circ} \mathrm{C}$ have a movement with the underground temperature.

Therefore, the minimum thermal insulation by depths was deduced by finding the U-factors that make the inside-surface temperature of the earth-covered wall closer to that of the aboveground wall. Table 4 shows the minimum thermal insulation by $1 \mathrm{~m}, 3 \mathrm{~m}, 5 \mathrm{~m}, 7 \mathrm{~m}$, and $9 \mathrm{~m}$ of the depth for underground residential buildings in the central region.

Although it is desirable to strengthen the thermal insulation in the views of energy saving, most of the regulations in relation with insulation are prescribed by the rule of a concept of the lower limit. Therefore, this study proposed the minimum thermal insulation for the earth-covered wall.

In addition, Weather data of Busan as a south region and Jeju are obtained from the society of airconditioning \& refrigerating engineers of Korea. And also, in equation (1) that calculates the underground temperature, its variables by Busan and Jeju regions were furnished by the meteorological observatory. Finally, table 5 shows the minimum thermal insulation by regions and depths. 


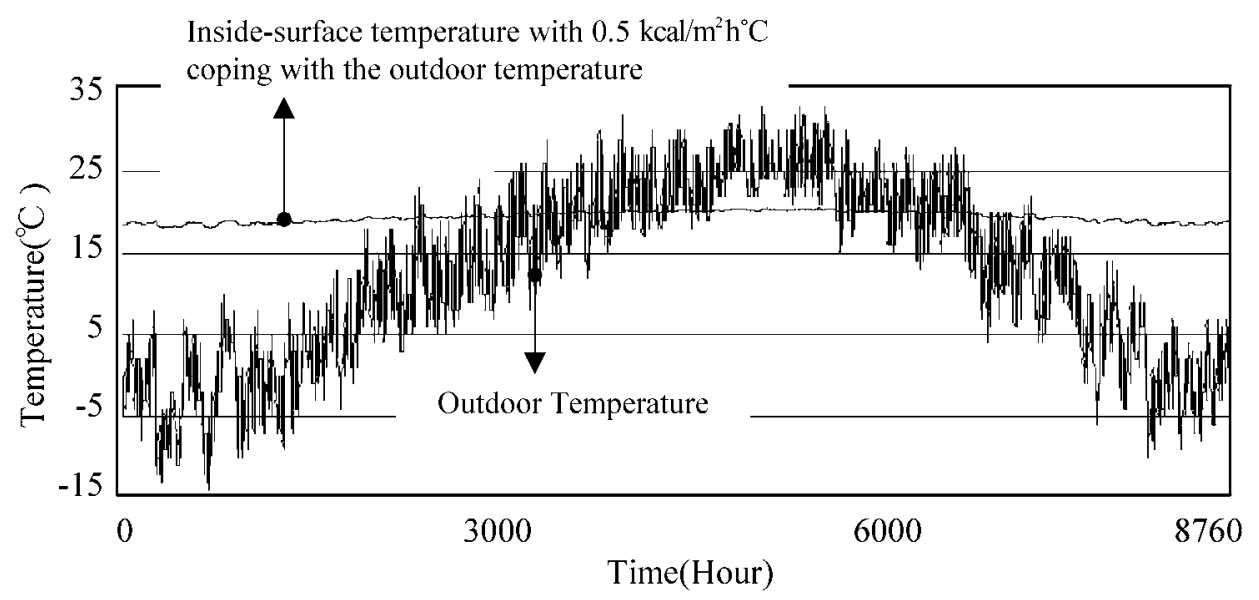

Fig.7. The Inside-Surface Temperature of Aboveground Wall, Coping with the Outdoor Temperature

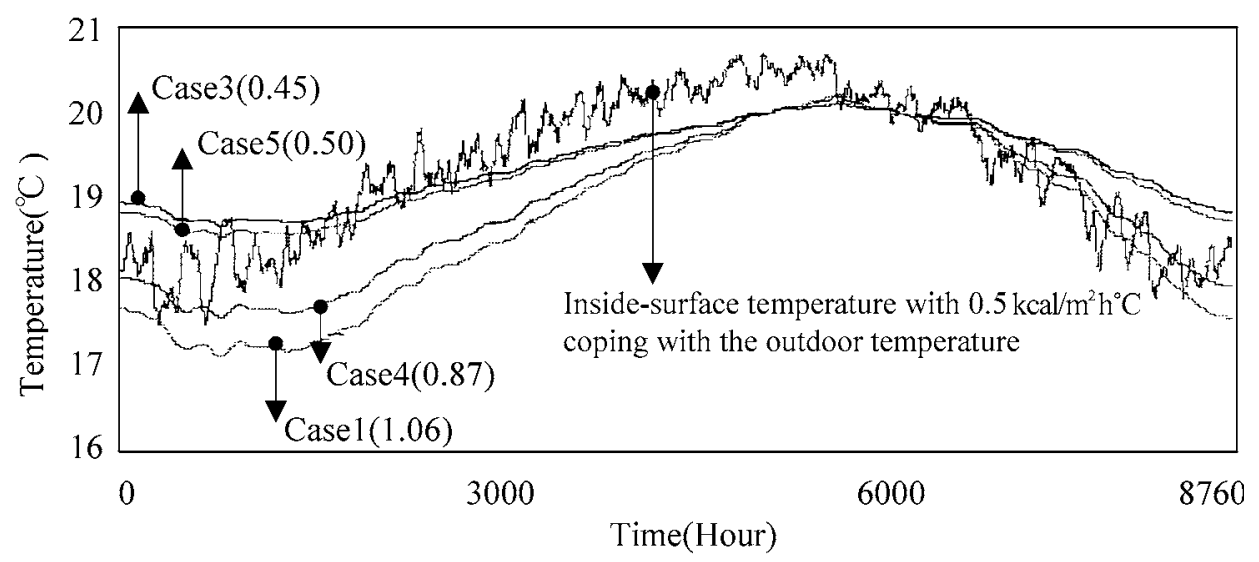

Fig.8. The Inside-Surface Temperature Coping With The Underground Temperature(I)(at $1 \mathrm{~m}$ of the depth in Seoul)

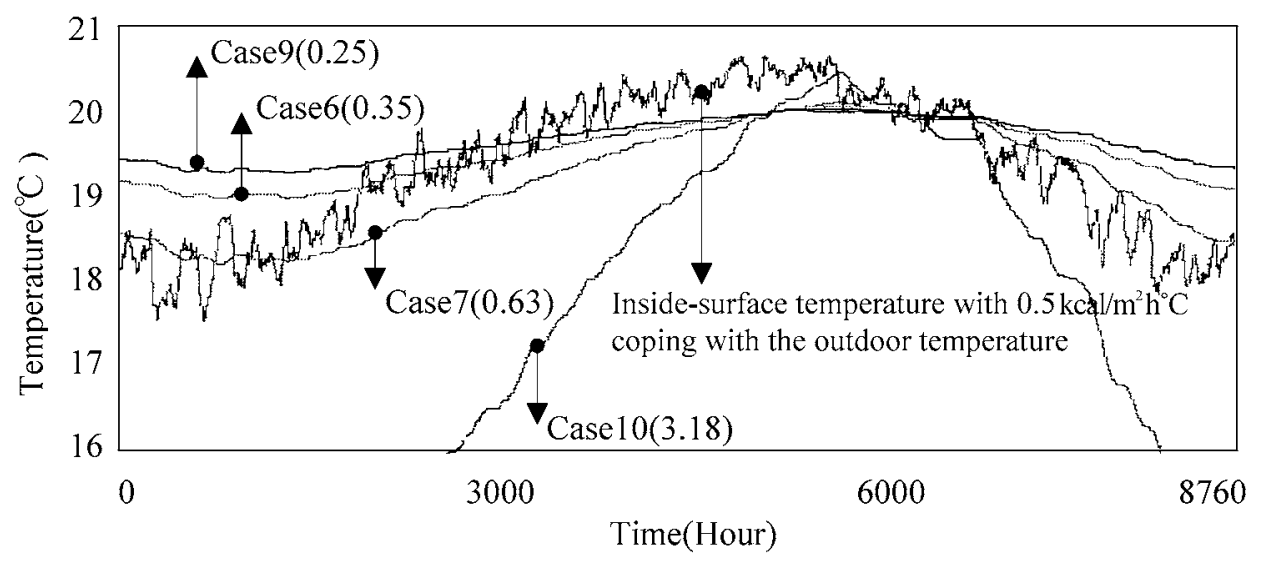

Fig.9. The Inside-Surface Temperature Coping With The Underground Temperature(II)(at $1 \mathrm{~m}$ of the depth in Seoul)

Table 4. Minimum Insulation Standards of The Earth-Covered Wall In Seoul

[Unit: $\left.\mathrm{kcal} / \mathrm{m}^{2} \mathrm{~h}^{\circ} \mathrm{C}\right]$

\begin{tabular}{ccccccc}
\hline Building & Above Ground & \multicolumn{5}{c}{ Underground } \\
\cline { 3 - 6 } Components & & $1 \mathrm{~m}$ & $3 \mathrm{~m}$ & $5 \mathrm{~m}$ & $7 \mathrm{~m}$ & $9 \mathrm{~m}$ \\
\hline Underground Walls & Less Than & Less Than & Less Than & Less Than & Less Than & Less Than \\
& 2.90 & 0.65 & 1.00 & 1.15 & 1.30 & 1.30 \\
\hline
\end{tabular}


Table 5. Minimum Insulation Standards of The Earth-Covered Wall

\begin{tabular}{|c|c|c|c|c|c|c|}
\hline \multirow{2}{*}{$\begin{array}{l}\text { Building } \\
\text { Components }\end{array}$} & \multirow[t]{2}{*}{ Above Ground } & \multicolumn{5}{|c|}{ Underground } \\
\hline & & $1 \mathrm{~m}$ & $3 m$ & $5 \mathrm{~m}$ & $7 \mathrm{~m}$ & $9 \mathrm{~m}$ \\
\hline Central District & $\begin{array}{c}\text { Less Than } \\
0.50\end{array}$ & $\begin{array}{c}\text { Less Than } \\
0.65\end{array}$ & $\begin{array}{c}\text { Less Than } \\
1.00\end{array}$ & $\begin{array}{c}\text { Less Than } \\
1.15\end{array}$ & $\begin{array}{c}\text { Less Than } \\
1.30\end{array}$ & $\begin{array}{c}\text { Less Than } \\
1.30\end{array}$ \\
\hline Southern District & $\begin{array}{c}\text { Less Than } \\
0.65\end{array}$ & $\begin{array}{c}\text { Less Than } \\
0.80\end{array}$ & $\begin{array}{c}\text { Less Than } \\
1.20\end{array}$ & $\begin{array}{c}\text { Less Than } \\
1.50\end{array}$ & $\begin{array}{c}\text { Less Than } \\
1.60\end{array}$ & $\begin{array}{c}\text { Less Than } \\
1.60\end{array}$ \\
\hline Jeju District & $\begin{array}{c}\text { Less Than } \\
1.00\end{array}$ & $\begin{array}{c}\text { Less Than } \\
1.30\end{array}$ & $\begin{array}{c}\text { Less Than } \\
1.80\end{array}$ & $\begin{array}{c}\text { Less Than } \\
2.30\end{array}$ & $\begin{array}{c}\text { Less Than } \\
2.60\end{array}$ & $\begin{array}{c}\text { Less Than } \\
2.60\end{array}$ \\
\hline
\end{tabular}

\section{Conclusion}

Seoul, the largest city in Korea, has recently reached the limit of space availability due to its population explosion. Its usage of underground space may be expanded from temporary space to residential space in the future. However, there is no thermal insulation standard, considering the thermal characteristics of the underground, for underground residential spaces of buildings.

The purpose of this study is to provide the regional insulation criterion of earth-covered walls for underground residential buildings in Korea by using a numerical simulation program. This study was started from the idea that thermal condition of underground residential space must be closer to that of aboveground residential space.

A brief summary of the results is given as follows;

First, According to the analysis result of monthly average underground temperature in Seoul for 30 years, although its annual temperature is varied from -5 to $25^{\circ} \mathrm{C}$ by heat of the ground from air and solar, the underground below $5 \mathrm{~m}$ of the depth from the surface, is not affected. And also the underground temperature below $9 \mathrm{~m}$ of the depth converges into the specific point $14.2^{\circ} \mathrm{C}$ in case of Seoul in Korea.

Secondly, the program was developed to predict the underground temperature by Mayer's equation. The difference between the predicted temperature and the measured temperature was less than $3 \%$.

Thirdly, to find the minimum insulation of the earthcovered wall, the numerical simulation was conducted case by case under the assumption that the inside-surface temperature of the earth-covered wall by depths becomes closer to the inside-surface temperature of the aboveground wall with the minimum insulation standard of residential buildings. Cases with about $0.6 \mathrm{~s} \mathrm{kcal} / \mathrm{m}^{2}$ $\mathrm{h}^{\circ} \mathrm{C}$ have similar variations to the variation of the insidesurface temperature that copes with the outdoor temperature. Cases with less than $0.5 \mathrm{kcal} / \mathrm{m}^{2} \mathrm{~h}^{\circ} \mathrm{C}$ has higher insulation level than that of the aboveground wall. In winter, Cases with about more than $0.7 \mathrm{kcal} / \mathrm{m}^{2} \mathrm{~h}^{\circ} \mathrm{C}$ have lower variations than the variation of the insidesurface temperature that copes with the outdoor temperature. It means that their insulation levels are inadequate to the central region. In particular, the insidesurface temperature of the case with $3.18 \mathrm{kcal} / \mathrm{m}^{2} \mathrm{~h}^{\circ} \mathrm{C}$ have a movement with the underground temperature.

Finally, the minimum thermal insulation by depths was deduced by finding the U-factors that make the insidesurface temperature of the earth-covered wall closer to that of the aboveground wall.

\section{References}

1) B. Bouchet, M. Frontoynont, (1996) Day-lighting of underground spaces: design rules, Energy and buildings 23, pp.293-298

2) Claesson, B.Eftring, (1980) Optimal distribution of thermal insulation and ground heat loss, Document D 33, Swedish Council Of Building Research.

3) S. Choi, M. Krarti, (2000) Thermally optimal insulation distribution for underground structures, Energy and buildings 32, pp.251-265

4) J. Speltz, (1980) A numerical simulation of transient heat flow in earth sheltered buildings for seven selected US cities, MS Thesis, Trinity University.

5) P.H. Shipp, E. Pfender, T.P. Bligh, (1981) Thermal characteristics of a large earth-sheltered buildings, Underground Space 6, pp.5364

6) R.F. Szydlowski, T.H. Kuehn, (1981) Analysis of transient heat loss in earth-sheltered structures, Underground Space 5(4), pp.25-37

7) M. Krarti, D. Claridge, (1990) Two-dimensional heat transfer from earth-sheltered buildings, ASME Journal of Solar Engineering 12(1), pp.43-50

8) Jeong S.I., (1986) A study on the optimum distance of the boundary condition for the analysis of the underground temperature in steady state, AIK journal v.2, n4, pp.169-175

9) Glen E. Mayers, (1971) Analytical methods in conduction heat transfer, McGrew-Hill Inc., pp.173-177

10) ASHRAE, (1980) ASHRAE Standard 90-80-Energy Conservation in New Building Design

11) Saris, (1985) Two dimensional steady state temperature distributions and heat flows in square corners, Building and Environmental, Vol.20, no.1,

12) Song S.Y., (1998) An Experimental study to evaluate the thermal performance of the optimal insulation details for the thermal bridges in apartment building envelope, AIK journal v.13, n.9, pp. 197206

13) KICT, (1997) Development of thermal insulation design \& construction system of buildings, Korea Institute of Construction Technology

14) Lee K.H., (1997) Development of the construction technology for underground living space (iv), Korea Institute of Construction Technology

15) Yonsei University, (1999) Developing insulation design standards and techniques for the underground space in apartment buildings, Korea Institute of Construction Technology

16) Kasai, K. and Yashiro, T. (2001) Elicitation of subjective probabilities for risk analysis. Journal of Asian Architecture and Building Engineering, 1 (1), 77-82

17) Underground Space Center, (1991) Underground Space Design, University of Minnesota, USA 